Agro-Science Journal of Tropical Agriculture, Food, Environment and Extension Volume 16 Number 2 (May 2017) pp. 1 - 8

ISSN 1119-7455

\title{
ANALYSIS OF FARM SIZE AND RESOURCE USE EFFICIENCY IN SELECTED ARABLE CROP PRODUCTION IN URUAN LOCAL GOVERNMENT AREA OF AKWA IBOM STATE, NIGERIA
}

\author{
Effiong, E.O. ${ }^{1}{ }^{1 d i o n g, ~ C . I . ~}{ }^{2}$ and Emem, D. ${ }^{3}$ \\ ${ }^{1}$ Department of Agricultural Economics \& Extension, University of Uyo, Uyo, \\ Akwa Ibom State, Nigeria \\ ${ }^{2}$ Department of Agricultural Economics \& Extension, University of Calabar, Calabar, \\ Cross River State, Nigeria \\ ${ }^{3}$ Department of Agricultural Economics and Extension, University of Uyo, Akwa Ibom State, Nigeria. \\ e-mail address: etim4effiong@gmail.com
}

\begin{abstract}
The study evaluated resource use efficiency in selected arable crop production among small and large farm in Uruan Local Government Area of Akwa Ibom State, Southern Nigeria. Specifically, the study estimated the production function of small and large farm owners, estimated their production elasticities and return to scale. It also estimated their respective allocative efficiency and identified the major constraints to resource use faced by this group of farmers in the study area. A multi-stage random sampling technique was used in selecting four cells out of six cells that make up Uruan Block, five villages from each cell and six farmers from each village. i.e three small farm size and three large farm size owners were selected. Data were collected with the aid of well structured questionnaire from one hundred and twenty arable crop farmers. Data was analyzed using multiple regression analysis and efficiency ratio. Results show that small farm arable crop farmers under utilized all their resources while large farm owners over utilized their land labour, capital inputs and purchased inputs but under utilized their working capital. There was a significant relationship between revenue accruing from the sales of output and farm size, working capital and purchased inputs (fertilizer, seeds, cuttings and agro-chemicals) for both categories of farmers. There was increasing return to scale for arable crop producers in the area with 2.71 for small farm size and 1.02 for large farm size owners. In order to reduce the negative consequences of inefficient resource use, farmers should be educated by the government and relevant bodies on some fundamental and management practices that will help them attain efficiency in the use of their available resources.
\end{abstract}

Keywords: Farm Size, Resource Use, Arable Crop, Uruan LGA, Nigeria

\section{INTRODUCTION}

Agriculture in Nigeria as in most other developing countries is dominated by rural farmers and they constitute about 80 percent of the farming population. (Oladeebo, 2004). Several constraints which appear insurmountable limit the food crop production of these rural farmers with a prime emphasis on land which is the basic unit of production agriculturally and is being referred to as "farm". This constraint of land as a result of government policy like land tenure system coupled with its relative availability and affordability poses serious limitation to these farmers. As a result of this, the only medium through which land is available to these farmers for their production activities is through inheritance, lease and sometimes purchase which is often within their small economic capacities. This result in varying farm sizes for the farmers as well as different incentives to production. It is estimated that annual food supply in Nigeria would have to increase at an average rate of $5.9 \%$ to meet the growing food demand and to reduce importation significantly. (Obasi, 2007). Most studies show that aggregate foods production in Nigeria has been growing at about $2.5 \%$ per annum in recent years but the annual rate of population growth has been as high as $2.9 \%$. (Olayemi, 2008). The reality is that Nigeria has not been able to attain self sufficiency 
Analysis of Farm Size and Resource Use Efficiency in Selected Arable Crop Production

in food production despite its land productivity potentials. The constraint to the rapid growth of food production seems to be that of low crop yields as a result of inefficient allocation of available farm resources. (Likita, 2005). The question of how efficient rural farmers use their farm resources with respect to their respective farm sizes is of considerable interest to agricultural economics. Efficient farms make better use of existing resources and produce their output at the lowest cost. Land, labour, capital and managerial resources are inefficiently allocated thereby leading to decrease in their productivity and reduced agricultural output. (Okuneye, 2007). This decreased output in agriculture has led to continued importation of food to meet the need of the ever increasing population. It has been observed that food crop production in Uruan Local Government Area has remarkably declined as a result of consistent low yields over the years (Market Survey Report, 2010). This is visibly evident in the situation where few of these crops are readily available in local markets for purchase by consumers. This creates an avenue of high prices of the available food crops due to the fact that these crops are scarce. When faced with this, one may be compelled to ask "what could be responsible for these continuously observed low yields? It has been already established that in agriculture, low yields are as a result of inefficient allocation of the available resources with non-uniformity distributed farm sizes, labour intensive agricultural technology and rapid declining soil productivity. (Likita,2005). It has been argued that given the Nigerian land area of $923,768 \mathrm{~km}^{2}$ and an estimated population of over 100 million people with over 70 percent of the population involved in agriculture, there is no justification for continuous importation of staple food in the country. (Olayemi, 2008). The government is aware of these potentials and recently placed a ban on the importation of some staple food such as millet, rice, wheat that can be locally produced. (Likita, 2005) The ban has given serious challenge to the food crop farmers in Nigeria. Some of the identified constraints to increased food production are inadequate resources and inefficient allocation of these resources given the fact that agricultural production is a function of the quality and quantity of resources employed in production. In order to achieve increased production, these resources must be available and whatever quantities available must be efficiently used. Increase in resource efficiency is therefore a pre-requisite for increased agricultural production. (Ogunfowora et al, 1985). Inefficient allocation of resources in the agricultural sector calls for a closer examination of the nature of the relationship between farm sizes and resource use efficiency with a view of selecting an efficient farm size category among small and large farms towards which effort can be directed to achieve increased yield in agricultural productivity. In essence the study objectives will entail the estimation of production function for small and large scale farmers as well as estimating production elasticity and returns to scale for both sized farms. However, the study will also estimate the allocative efficiency indices for small and large farm sizes as well as identify the constraints to resource use for food crop producers for both sized farms.

\section{Theoretical Framework}

Efficiency analysis is an issue of interest among economists in recent times given that the overall productivity of an economic system is directly related to the efficiency of production of the components within the system. In essence, agricultural productivity is said to be a measure of efficiency as reported by Olayide and Heady, (1982). Moreover, maximum resource productivity implies obtaining maximum possible output from minimum set of inputs. In this context, optimal productivity of resource involves an efficient utilization of resources in the production process. Agricultural productivity is defined as a measure of efficiency in which an agricultural production system employs land, labour, capital and other resources towards producing outputs. A technically efficient farm produces maximum output from inputs used given location and environmental constraints and it maximizes resources used for any fived level of output. (Rahman et al , 2005). Profit maximization requires a farm to produce maximum output given the level of inputs employed (i.e technically efficient).

Farm size can be viewed or defined with respect to value of farm production, total capital invested, total area of land under cultivation as well as total labour employed or used on the farm. Based on the above criteria of farm size, small farm size has small or moderate physical and financial footprints in which the family provides at least as much farm labour as non family employees and management control is retained by the farm family. Small farms are farms with small area of land usually between 0.01 and 2.0 hectares, limited resources inputs, and produced mostly at a subsistence level. Large farms involved large fields which measures from 2.00 hectares and above with large and modern inputs such as agrochemicals and hired labour extensively in its production activities and operations. (Olayemi, 2008). 
Effiong, E.O. Idiong, C.I. and Emem, D.

The general agreement on farm sizes is that small and large farms systematically face different sets of factor prices giving them different access to resources and different incentives to produce. Generally, it could be said that the effective price of land and capital is usually higher for small farmers whereas effective price of labour is small. Consequently, output per unit of land for small farms is expected to be higher and they would appear to be more efficient. (Arnade, 2008). The same conclusions are likely to be valid when considering as an indicator of efficiency. The total factor productivity however is the ratio of farm output to the social cost of all factors of production. However, the very small farms probably have total social factor productivity lower than that of other farm sizes. Mijindadi (2000) however stressed that these general conclusions are subject to a number of exceptions especially in land rich countries and when the phenomenon is analysed in dynamic perspectives.

\section{Research Methodology}

Study Area: This study was carried out in Uruan Local Government Area of Akwa Ibom State, Southern Nigeria. It is located between latitude $6^{\circ}$ $40 \mathrm{~W}$ and longitude $7^{\circ} 20 \mathrm{E}$ in the North Western part of the state and occupies a large land mass of $422,352 \mathrm{sq} \mathrm{km}$ (Akwa Ibom State Ministry of Lands and Survey, 2008). The study area has a block on its own in the Akwa Ibom State Agricultural Development Programme and consists of forty seven (47) villages grouped into six (6) cells with each cell comprising of at least seven (7) villages. The area is richly endowed with fertile land suitable for cultivation of arable crops, rivers that harbour consumable aquatic lives, forest zones that supply firewood as source of fuel for the inhabitants, as well as good sand for construction and building purposes. Intercropping is the main cropping system practiced in the area. Major crops intercropped in the area are yam, cassava and maize and sometimes fluted pumpkin.

\section{Sampling Procedure and Method of Data Collection}

A multi-stage random sampling technique was used in selecting the respondents for the study. The first stage was the random selection of four out of the six cells. Another random sampling of five villages was carried out from each of the cell making a total of twenty villages for the study. Further more, six farmers involved in yam, maize and cassava production were randomly selected with three cultivating a farm less than two hectares in size and the other three cultivating a farm size greater than two hectares. This brought the total number of respondents to one hundred and twenty for the study. These farmers were selected from the list of farmers involved in yam, maize and cassava production in the area. This list was collected from the extension agents in charge of each cell and used as a sampling frame. Primary and secondary data were used for the study. Primary data was collected through a cross sectional survey involving 120 respondents using well structured questionnaire and oral interviews. Information about crop yield, various inputs, prices of inputs and outputs was also collected from primary source. Secondary data was collected from monographs, journals, CBN bulletins, and other documented reports in the study area.

\section{Analytical Techniques}

The production function for small and large farm sizes was estimated using multiple regression analysis. Implicitly, the production function is expressed thus:

$\mathrm{Y}=\mathrm{f}(\mathrm{X} 1, \mathrm{X} 2, \mathrm{X} 3, \mathrm{X} 4, \mathrm{X} 5 .+\mathrm{e})$

Where:

$\mathrm{Y}=$ Total Revenue realized from the sales of output (Naira)

$\mathrm{X} 1=$ Farm size (hectares)

$\mathrm{X} 2=$ Labour (man-days)

X3=Operating capital ( Naira )

$\mathrm{X} 4=$ Capital inputs i.e depreciation in farm

equipment and Machines. (Naira)

X5=Purchased inputs. i.e fertilizers, agrochemicals, seeds cuttings (Naira)

$\mathrm{e}=$ error term

Allocative efficiency estimation will be achieved using efficiency ratio which implies the ratio between the marginal value productivity and the marginal factor cost of each input for both farm categories.

\section{RESULTS AND DISCUSSION}

Table 1 indicates that the lead equation for the small farm size category was selected based on the magnitude of the coefficient of multiple regression, the more significant variables and the appropriateness of the signs of the estimated coefficient. This however led to the choice of the linear function. From the results in Table 1, the coefficient of multiple determination showed that the independent variables accounted for about $71 \%$ of the total variation in the revenue gotten from the sales of crop output in the study area. All the input coefficients except that of capital inputs has positive sign. Farm size, working capital and purchased inputs played significant roles in the variation in food crop output and revenue of small 
farm farmers in the area. This is in agreement with a-priori expectation and an indication that increasing the level of farm size, working capital and purchased inputs such as fertilizer, seeds, cuttings and agro chemicals would lead to an increased food crop output which will translate into increased revenue for the small size farmers in the study area. Labour and capital inputs were not significant implying that the variables were unable to explain the variation in the level of revenue accruing from the sales of the crop output of small farm holders in the study area. Labour in essence suggests that if manual labour is substituted with machines, it may enhance farm output and revenue of small farm owners. The lead equation for large farm category was selected based on the magnitude of coefficient of multiple determination, the more significant variables and the appropriateness of the signs of the estimated coefficients. This guided the choice of the double log functional form as the lead equation for the large farm category. The coefficient of multiple determination from the estimate indicates that the independent variables accounted for about $72 \%$ of the total variation in the dependent variable. In essence, the results showed that farm size, working capital and purchased inputs had significant contribution to the crop output of large farm size farmers.
The coefficients of labour and capital inputs were not significant. Oladeebo (2004) however stressed that farmers within a particular area may rarely use modern equipments and machines for farm operations which might be caused by traditions, poverty and lack of education as well as poor extension contact. This group of farmers however rely on hoes and cutlasses for their operations. It is expected that when there is an increase in the intensity of use of farm inputs, that farm output and revenue is likely to also increase and this may be responsible for the positive signs of these coefficients of these variables. With respect to this group of large farm category in the study area, farm size, labour, working capital, capital inputs and purchased inputs such as fertilizers, seeds, cuttings and agro-chemicals are the important factors of production.

The significance of farm size, operating capital and that of purchased inputs is a clear indication that regardless of the scale of operation, these variables were very paramount to the output of arable crop producers in the study area. This however agrees with the findings of Alimi (2000) in a study in Oyi Local Government Area in Anambra State that farm size, working capital and purchased inputs were significant inputs for output maximization for rice producers in the area.

Table 1: Regression estimates for small farm sizes in arable crop production in the study area

\begin{tabular}{lllll}
\hline $\begin{array}{l}\text { Production } \\
\text { Factors }\end{array}$ & $\begin{array}{l}\text { Linear } \\
\text { Model }\end{array}$ & $\begin{array}{l}\text { Double log } \\
\text { Model }\end{array}$ & $\begin{array}{l}\text { Semi-log } \\
\text { model }\end{array}$ & $\begin{array}{l}\text { Exponential } \\
\text { Function }\end{array}$ \\
\hline b0(Constant) & 5370.225 & 3.158 & -34632.334 & 3.978 \\
& $(2.568)^{* *}$ & $(5.779)^{*}$ & $(-1.256)$ & $(89.396)^{*}$ \\
X1(Farm size) & 8822.930 & 0.321 & 15204.309 & 0.189 \\
$(2.94)^{* *}$ & $(2.637)^{* *}$ & $(2.474)^{* *}$ & 1.786 \\
X2(Labour) & 2.676 & 0.021 & 1223.544 & $(0.054)$ \\
& $(0.171)$ & $(0.290)$ & $(0.329)$ & 8.486 \\
X3(Operating & -0.500 & 0.071 & 3828.352 & $(1.936)^{* * *}$ \\
capital) & & & & -3.362 \\
& $(1.900)^{* * *}$ & $(0.779)$ & $(0.833)$ & $(-0.978)$ \\
X4(Capital inputs) & -0.707 & -0.046 & -0.706 & 4.832 \\
X5(Purchased & $(-0.437)$ & $(-0.856)$ & $(-0.262)$ & 12757.151 \\
inputs) & 2.190 & 0.295 & & $(6.621)^{*}$ \\
R & & & $(8.090)^{*}$ & 0.610 \\
Adjusted R & $(4.493)^{*}$ & $(3.610)^{*}$ & 0.477 & 0.577 \\
F-ratio & 0.713 & 0.517 & 0.440 & 21.502 \\
\hline Source: & 21.809 & 0.485 & 18.430 & \\
\hline
\end{tabular}

Source: Field

survey, 2016.

Note: Figures in brackets represents t-ratios.

$*, * *, * * *$ are probability levels at $1 \%, 5 \%$ and $10 \%$ respectively 
Effiong, E.O. Idiong, C.I. and Emem, D.

Table 2: Regression estimates for large farm sizes in arable crop production in the study area.

\begin{tabular}{lllll}
\hline Production & Linear & Double & Semi-Log & $\begin{array}{l}\text { Exponential } \\
\text { Function }\end{array}$ \\
\hline b0(Constant) & Model & Model & Model & 4.286 \\
& 93.036 & 3.106 & -150.923 & $(95.384)^{*}$ \\
X1(Farm size) & $(0.019)$ & $(9.126)^{*}$ & $(-2.989)^{* *}$ & 0.082 \\
& 978.984 & 0.667 & 962.872 & $(3.129)^{*}$ \\
X2(Labour) & $(3.532)^{*}$ & $(4.161)^{*}$ & $(4.047)^{*}$ & 0.008 \\
& 0.980 & 0.034 & 478.448 & $(0.408)$ \\
X3(Operating capital) & $(0.496)$ & $0.575)$ & $(0.552)$ & 6.008 \\
X4(Capital inputs) & 0.780 & 0.144 & 187.814 & $(1.881)^{* * *}$ \\
& $(1.809)^{* * *}$ & $(1.771)^{* * *}$ & $(1.958)^{* * *}$ & 6.257 \\
X5(Purchased inputs) & 0.313 & 0.016 & -168.981 & $(0.576)$ \\
R & $(0.271)$ & $(0.411)$ & $(0.299)$ & 6.585 \\
Adjusted R & 1.625 & 0.154 & 213.252 & $(2.101)^{* *}$ \\
F-ratio & $(4.879)^{*}$ & $(2.973)^{* *}$ & $(2.775)^{* *}$ & 0.759 \\
\hline Source: Field Survey & 0.866 & 0.772 & 0.752 & 0.732 \\
\hline
\end{tabular}

Source: Field Survey Data, 2016.

Note: Figures in brackets represents $\mathrm{t}-$ ratios

$*$,** and $* * *$ represents probability levels at $1 \%, 5 \%$ and $10 \%$ respectively.

Table 3. Input elasticities and return to scale for small farm size farmers in the study areea.

\begin{tabular}{|c|c|c|c|}
\hline Input & $\begin{array}{l}\text { Average } \\
\text { Physical } \\
\text { Product } \\
\text { (APP) }\end{array}$ & $\begin{array}{l}\text { Marginal } \\
\text { Physical } \\
\text { Product } \\
\text { (MPP) }\end{array}$ & $\begin{array}{l}\text { Elasticity of } \\
\text { Production(Ep) }\end{array}$ \\
\hline X1(Farm size) & 24,147 & 18.27 & 0.0008 \\
\hline X2(Labour) & 196.4 & 0.68 & 0.0035 \\
\hline $\begin{array}{l}\text { X3(Working } \\
\text { capital) }\end{array}$ & 4.93 & 5.07 & 1.03 \\
\hline $\begin{array}{l}\text { X4(Capital } \\
\text { inputs) }\end{array}$ & 34.71 & -1.02 & -0.03 \\
\hline $\begin{array}{l}\text { X5(Purchased } \\
\text { inputs) }\end{array}$ & 7.93 & 13.80 & 1.74 \\
\hline Return to Scale & ---- & ---- & 2.74 \\
\hline
\end{tabular}

Table 4. Input elasticities and return to scale for large farm size farmers in the study area.

\begin{tabular}{llll}
\hline Input & $\begin{array}{l}\text { Marginal } \\
\text { Physical } \\
\text { Product } \\
\text { (MPP) }\end{array}$ & $\begin{array}{l}\text { Elasticity } \\
\text { Production }\end{array}$ & \\
& 0.667 & 0.667 \\
X1 (Farm size) & 0.034 & 0.034 \\
X2 (Labour) & 0.144 & 0.144 \\
X3 (Working capital) & 0.016 & 0.016 \\
X4(Capital inputs) & 0.016 \\
X5 (Purchased inputs) & 0.154 & 0.154 \\
Return to Scale & & 1.02 \\
\hline Source: Field Survey & & \\
Data 2016 & &
\end{tabular}

Estimates of Input Elasticities and Return to Scale for Arable Crop Producers in the Study Area Table 3 shows the elasticity of production which is the percentage change in output as a result of a percentage change in input indices for small farms. The values were 9.3, 2.7, 0.50, - 0.71 and 2.19 for farm size to purchased inputs. This implies that a unit increase in farm size, labour, operating capital and purchased inputs will lead to a $9.3 \%, 2.7 \%$, $0.50 \%$ and $2.9 \%$ increases in the crop output for small-farm arable crop producers in the area. Therefore it implies that if intensity of use in farm implements is reduced, it will lead to a $0.71 \%$ increase in farm revenue. The summation of the output elasticities which is an indication of the return to scale indicates an increasing return to scale for small farm crop producers in the area as shown by the value 2.74. it can therefore be inferred that small farm owners involved in food crop production are likely to earn more revenue by increasing their scale of operation. Ajibefun (2007) however agrees with this assertion that small scale farm holders involved in crop production can as well have increasing return to scale. For large farm category, the input coefficients which also represents the Marginal Physical Product (MPP) are the direct production elasticities using the double log production function. For the large farm, input elasticities are 0.067,0.034,0.144,0.016 and 0.154 for farm size, labour operating capital, capital inputs and purchased inputs respectively. This means that an increase in a unit of farm size, labour, working capital, capital inputs and purchased inputs will bring about $0.66 \%, 0.034 \%$, $0.144 \%, 0.016 \%$ and $0.154 \%$ increase productivity of food crops for large farm owners in the area. The summation of the output elasticities for the large farm category resulted in 1.02. This also indicates an increasing return to scale for large farm arable crop producers. This means that large scale farm category farmers will be increasing their revenue by increasing their scale of operation. On the whole, although both small and large farm sized farmers are operating on an increased return to 
Analysis of Farm Size and Resource Use Efficiency in Selected Arable Crop Production

scale, small farms have the greater potential for increased productivity with a unit increase in the inputs concerned as shown in the greater value of return to scale. From the estimates of input elasticity, we can deduce that farm size is the most important factor that affects productivity among the two classes of farms. Therefore, to increase farm productivity, emphasis should be placed on increasing land availability to farmers. According to Rahman (2005), land tenure and land fragmentation practices have left genuine farmers with very small parcel of land to farm.

\section{Efficiency Indices for Arable Crop Farmers in the Study Area}

To access the level of resource use efficiency of arable crop farmers in the area, the Marginal Value Product (MVP) and the Marginal Factor Cost (MFC) of each input was computed. The Marginal Value Productivity has been described as the yardstick for measuring efficiency of resource use at a given level of technology and prices of inputs and outputs. (Eyo, 2002). The MVP provides a framework for effecting resource adjustment on the farm. When the MVP is positive, it is an indication that using more of a given resource could increase output. However, the MVP must be compared with the MFC in order to determine how worthwhile it is to increase the level of resource use. The difference between the MVP and the MFC indicates the level of resource use and also gives the scope of resource adjustment necessary to attain economic optimum.

Arable crop producers in the area were assumed to operate in a purely competitive market. Thus, the price per unit of input was used as the marginal factor cost. The MFC for farm size was $\$ 2,000$ on the average for a hectare of land for small farms in the area. This was the average price paid for leasing a hectare of land as at the production period, whereas that of large farms was $\$ 1,500$ per hectare. The MFC of labour was N600 which was the average wage rate of labour paid per man-day. The MFC of operating capital was 1.06 which is the prevailing interest rate of capital paid per thousand of naira during the production period. For purchased inputs, the MFC was the summation of the MFC of fertilizer per kilogram which was $¥ 160.00$. Moreover, seeds per cup was $¥ 40.00$, cuttings was $\$ 300.00$ per kilogram for cassava cutting and agrochemicals stood at $\$ 1,200$ on the average per can. This brought the Marginal Factor
Cost of purchased inputs to 1,700 in the study area. Furthermore, estimates of the marginal value productivity and allocative efficiency of farmers in the area are given below. The MVP of all the inputs for small farms is positive and greater that one. Table 5 shows higher MVP values for land $\left(X_{1}\right)$, labour $\left(X_{2}\right)$ and purchased inputs $\left(X_{5}\right)$. This indicates that land is the most productive resource followed by labour and purchased inputs for small farm owners. The very high MVP value of land (farm size) may be due to the fact that farmers cultivate high value crops like yam, maize and cassava in the area. Eyo (2002) stressed that a resource is efficiently utilized if the ratio of its MVP to MFC i.e allocative efficiency is equal to one. A ratio less than one indicates over utilization of the resource and output and revenue can be increased by decreasing the rate of use of the resource whereas a ratio greater than one indicates under utilization of the resource with output and revenue likely to be increased or maximized if the rate of use of the resource is increased. Based on this analysis, it can be deduced that small farm sizes under utilized all their resources.

The under utilization of farm size for small farm owners may be due to the cultivation of small farm sizes as a result of higher factor prices of land in the area and the use of crude farming implements. This agrees with the findings of Obasi (2007). The under utilization of labour may be due to the high wage rate of labour that does not favour the small farm owners. Working capital was also under utilized owing to the fact that small farm owners are faced with the problem of inadequate capital for their production activities as they are only left to the mercies of their relatively small equity. Small farm owners lack access to agricultural credit because of their low credit worthiness as a result of their scale of operation. This makes the financial institutions consider granting loans to small farm size owners as risky and hence increase the interest rate of capital for them which ultimately make them reluctant to borrowing. Under utilization of purchased inputs by small farmers may be due to the unavailability and relatively high cost of fertilizer and agro chemicals to the small farm owners and it may also be as a result of non existence of the use of agro chemicals in crop production among small farm owners and the use of seeds and cuttings below the recommended rate. 
Effiong, E.O. Idiong, C.I. and Emem, D.

Table 5. Allocative efficiency indices for small farm sizes in food crop production in the study area.

\begin{tabular}{|c|c|c|c|c|c|}
\hline Input & $\begin{array}{l}\text { Input } \\
\text { Price }\end{array}$ & $\begin{array}{l}\text { Output } \\
\text { price }\end{array}$ & MPP & MVP & $\begin{array}{l}\text { Allocative } \\
\text { Efficiency }\end{array}$ \\
\hline $\mathrm{X} 1$ & 2000 & 1400 & 18.27 & 25,578 & 12.79 \\
\hline $\mathrm{X} 2$ & 600 & 1400 & 0.68 & 952 & 1.59 \\
\hline X3 & 1.06 & 1400 & 5.07 & 7,098 & 6696.2 \\
\hline$\times 5$ & 1700 & 1400 & 13.80 & 19,320 & 11.36 \\
\hline
\end{tabular}

Table 6. Allocative efficiency indices for large farm sizes in arable crop production in the study area.

\begin{tabular}{llllll}
\hline Input & $\begin{array}{l}\text { Input } \\
\text { Price }\end{array}$ & $\begin{array}{l}\text { Output } \\
\text { Price }\end{array}$ & MPP & MVP & $\begin{array}{l}\text { Allocative } \\
\text { Efficiency }\end{array}$ \\
\hline X1 & 1500 & 1400 & 0.667 & 933.8 & 0.68 \\
X2 & 600 & 1400 & 0.034 & 47.6 & 0.08 \\
X3 & 106 & 1400 & 0.144 & 201.6 & 190.19 \\
X4 & 1100 & 1400 & 0.016 & 22.4 & 0.02 \\
X5 & 1700 & 1400 & 0.154 & 215.6 & 0.13 \\
\hline
\end{tabular}

Source: Field Survey Data,2016.

Table 6 shows that the MVP of all the inputs in the large farm category was positive and greater than one. The highest MVP value for land shows that for large farm owners land is the most productive resource followed by working capital and purchased inputs. This high MVP for land may be due to the fact that farmers cultivate high value crops like yam, maize and cassava in the area. From these results in Table 6, large farm sizes over utilized their farm size $\left(\mathrm{X}_{1}\right)$, labour $\left(\mathrm{X}_{2}\right)$, capital inputs $\left(\mathrm{X}_{4}\right)$ and purchased inputs $\left(\mathrm{X}_{5}\right)$ and under utilized working capital. The over utilization of land may be due to the lower factor prices of the available land leading to unnecessary acquisition of large expanses of land which they cannot effectively cultivate or make intense use of (Obasi, 2007). Over utilization of labour is because large farm owners face the same factor cost of labour per manday with small farm owners which make them advantaged in the employment of labour above what is required than the small farm owners who cannot afford the cost of labour inn relation to their small scale production. It may also be as a result of the farmers spending more mandays of labour performing same tasks on repeated basis on food crop farms. This excessive use of labour tends to support the general belief of low labour productivity in agriculture which conforms to the findings of Oladunni (2006). Under utilization of working capital by the large farm owners could be as a result of the fact that agricultural banks are not available in the area for large scale farmers to have access to agricultural loans. This agrees again with the findings of Oladunni (2006) that unavailability of agricultural banks in the rural area pose a constraint to food crop producers in rural areas hence, limiting their utilization of working capital. Capital inputs were also over utilized which implies that rather than embracing mechanization, they preferred a more intensive use of their traditional equipment. Purchased input was also over utilized which could be as a result of the fact large farm holders have more access to fertilizers, more seeds, cuttings and agrochemicals because of their economic capacity (Obasi, 2007). Relating the allocative efficiency indices of arable crop producers in the area to the classical production function, it is observed that small farm size producers were as at the production year considered for the study operating within the stage one of the classical production function as indicated by their indices that signified under utilization. Large farm size farmers on the other hand were operating within the stage three of the classical production function as indicated by their efficiency indices that signified over utilization of resources.

\section{CONCLUSION AND \\ RECOMMENDATIONS}

This study provides some useful information on resource productivity and efficiency of farmers involved in arable crop production in Uruan Local Government Area. Resource use efficiency analysis showed that small farm size crop producers under utilized all their resources while large farm size crop producers over utilized their resources except working capital. Generally, this result implies that within the limits of statistical error, none of the inputs was efficiently allocated by food crop producers in the area. This result suggests there exists the possibility of increasing output under the existing level of technology through the use of lower levels farm size, labour, capital and purchased inputs and increased use of working capital in agriculture by large farm owners and increased level in the use of farm size, labour, working capital and purchased inputs by small farm holders. To attain optimality or efficiency in the use of resources and to reduce the negative consequences of poor resource allocation and utilization by crop producers in the area, the following recommendations are made based on the findings.

- Farmers should be motivated and encouraged to increase their farm size to enable farm inputs such as machines and agro chemicals have more pronounced effect on increasing farm productivity. Government can as well help by providing tractor hiring services at affordable rate to farmers so as to enable them increase on their scale of operation. 
Analysis of Farm Size and Resource Use Efficiency in Selected Arable Crop Production

- There is need to sensitize the small farm size farmers on the possible advantages of using agrochemicals in arable crop production and also training them on the appropriate rate for planting seeds in the area.

- Prices of inputs should be subsidized in practice for the farmers and a monitoring team should be put in place to monitor the distribution of these inputs to practical farmers and not portfolio farmers.

- Arable crop farmers in the study area should be enlightened on the appropriate level of input use to avoid over or under utilization of these resources.

- Farmers in the area should be educated on some fundamental farm management skills which will at least enable them to plan, evaluate and appraised their farm business and also enable them to predict the economic implications of their investments in arable crop production.

\section{REFERENCES}

Arnade, C (2008) Using a Linear Programming Approach to measure International Agricultural Efficiency and Productivity Journal of Agricultural Economics, 49: (1): pp. 67 - 84.

Asiabaka, C.C (2007)International Organizations Role in Agriculture and Rural Development: The Need for Human Resources Development: Nigerian Journal of Rural and Community Development, 1 (2) : pp $94-101$.

Eyo, E.O and M. S. Igben (2002) “ Agricultural Economics: An Introduction to Basic Concepts and Principles" Best Prints Business Press, pp 113 116.

Fasrrel, M.J. (1957) "The Measurement of Production Efficiency, Journal of Royal Statistics Soc. Serial A, pp 120.
Likita, T (2005) "Technical Efficiency in Arable Crop Production in Kebbi State, Nigeria”. Journal of Agriculture and Food Security, Vol. 3:. No.2 pp $165-174$.

Mijindadi, N and Norman D (2000) "Determination of Technical Efficiency on Traditional Farms in Zaria Area of Northern Nigeria" Nigerian Journal of Agricultural Economics, 1: (1) pp 48 - 57.

Obasi, P.C (2007) “ Farm Size and Productivity Relationship among Arable Crop Farmers in Imo State, Nigeria: International Journal of Agriculture and Rural Development, Vol. 9:. pp 91 - 99.

Ohajianya, D.O (2006) “ Resource Use Efficiency of Land Owners and Tenants in Food Crop Production in Imo State, Nigeria. Journal of Sustainable Tropical Agriculture, Vol. 17:.pp 26 - 30.

Okuneye, P.A (1995) " Efficiency among Nigerian Household and Cooperative Group Farms": A Comparative Analysis: Journal of Agriculture Economics; 35: (2) : pp $253-275$.

Oladeebo, J.O (2004) “ Resource Use Efficiency of Small and Large Scale Farmers in South Western Nigeria; Implication for Food Security". International Journal for Food and Agricultural Research, Vol.1 No. 12:. pp 227 -235.

Oladunni, O.A (1996) "Technical Efficiency Differentials in Agricultural Production: Implication for Agricultural Development in Nigeria. The Nigerian Journal of Agriculture and Rural Management; Vol. 1:. (1) pp 51-59.

Oluwatayo, O.S and D.O. Ohajianya and P.C.Obasi (2004): "Resource Use Efficiency of Maize Farmers in Rural Nigeria: Evidence from Ekiti State; World Journal of Agricultural Sciences, Vol. 4: (1) : pp 91 $-99$

Rahman, S.A (2005) “ Technical Efficiency in Sorghum -Based Cropping Systems in Soba Area of Kaduna State, Nigeria. Nigerian Journal of Research in Science and Management; Vol. 3: (1) pp $100-104$. 